\title{
Influence of Laser Therapy and Muscle Relaxant on the Masseter Muscle under Occlusal Wear - An Ultrastructural Study
}

\author{
Influencia de la Terapia Laser y Relajante Muscular en el \\ Músculo Masetero bajo Oclusión - Un estudio Ultraestructural
}

\author{
"Márcio Vieira Lisboa; *Antônio Luiz Barbosa Pinheiro; ${ }^{* *}$ Marcos André Vannier dos Santos; ${ }^{* *}$ Abrahão Fontes Baptista; \\ *Ana Paula Cavalcanti de Sousa; *Alberto de Aguiar Pires Valença Neto \& *Jean Nunes dos Santos
}

LISBOA, M. V.; PINHEIRO, B. A. L.; DOS SANTOS, V. M. A.; BAPTISTA, F. A.; DE SOUSA, C. A. P.; PIRES VALENÇA NETO, P. A. A. \& DOS SANTOS, N. J. Influence of laser therapy and muscle relaxant on the masseter muscle under occlusal wear-an ultrastructural study. Int. J. Morphol., 30(3):999-1006, 2012.

SUMMARY: The aim of this study was to analyze the influence of low-intensity laser therapy and muscle relaxant in the characteristic ultra structural masseter muscle occlusal wear. Animals and Methods: 40 male Wistar rats were randomly divided into four groups: the control group (GI), occlusal wear (G-II), laser occlusal wear (G-III), and the muscle relaxant occlusal wear (G-IV). Under general anesthesia given intraperitoneally, animals in groups II, III and IV had unilateral amputation of upper and lower molar cusps to simulate an occlusal wear situation. The masseter muscle G-III received laser therapy $(830 \mathrm{~nm}, 4 \mathrm{~J} / \mathrm{cm} 2,40 \mathrm{~mW}, \mathrm{f} \sim 2 \mathrm{~mm})$ and the procedure was subsequently repeated every other day for $14 / 30$ days. G-IV animals were treated with daily injection of dantrolene ${ }^{\circledR}(2.5$ $\mathrm{mg} / \mathrm{kg}$ in $0.5 \mathrm{ml}$ of $\mathrm{H}_{2} \mathrm{O}$ ). From 24 hours after the elimination peak. The animals were euthanized with an overdose of anesthesia on days 14 and 30 after the removal of the cusps and the ipsilateral masseter muscle was excised and divided in two, one half was routinely processed for light microscopy and other for electron microscopy. There was no statistical difference between each experimental group and the control and between periods in each experimental group. However, the muscle fibers in the G-II showed the most pronounced changes. There is no causal relationship between muscles fibers injuries and occlusion and, despite signs of muscular tissue injury were more evident in the occlusal wear group. Results indicates a moderate action of laser therapy and muscle relaxants in skeletal muscle.

KEY WORDS: Lasertherapy; Ultrastructure; Dental occlusion; Masseter muscle relaxant.

\section{INTRODUCTION}

The etiology of temporomandibular disorder (TMD) involves craniofacial morphology, head posture, stress, psychological factors, trauma, joint hyper mobility and infections as risk or contributing factors (Egelmark et al., 2003; Liljeström et al., 2005; Niemi et al., 2006; Prasad et al., 2007). In addition, the occlusion plays a key role on the temporomandibular joint as it may influence the functional activity of masticatory muscles, resulting in fatigue and muscular pain (Gesh et al., 2004; Sonnesen \& Svensson, 2008). Despite this, previous studies focusing on muscle activity in TMD patients have not provided convincing evidence that muscle hyperactivity occurs (Issa et al., 2006; Okano et al., 2007; Rodrigues \& Ferreira, 2003; Suvinen \& Kemppainen, 2007). Thus, the relationship between malocclusion and muscle morphofunctional aspects in the masticatory system is not yet fully understood (Bani et al., 1999).

Due to these aspects, several modalities of therapy have been approached for patients with temporomandibular joint (TMJ) dysfunction and chronic orofacial pain (Türp et al., 2007), in order to maximize their complementary actions. Among the therapies currently in use, muscle relaxants and low level laser therapy (LLLT) have been reported (Bani \& Bergamini, 2001; Carrasco et al., 2008; Emshoff et al., 2008). Muscle relaxants are prescribed to reduce skeletal muscle tone and chronic orofacial pain, and alleviate muscle hyperactivity (Bani \& Bergamini, 2011; Bani \& Bergamini, 2002; Hersh et al., 2008; Krause et al., 2004).

Biophotonic Center, School of Dentistry, Federal University of Bahia - Av. Araujo Pinho, 62, Canela, Salvador, 40110-150, Bahia, Brazil.

** Laboratory of Parasitology Biomorphology, Gonçalo Moniz Research Center - Oswaldo Cruz Foundation - Rua Waldemar Falcão, 121, Candeal, Salvador, 40296-710, Bahia, Brazil. 
LISBOA, M. V.; PINHEIRO, B. A. L.; DOS SANTOS, V. M. A.; BAPTISTA, F. A.; DE SOUSA, C. A. P.; PIRES VALENÇA NETO, P. A. A. \& DOS SANTOS, N. J. Influence of laser therapy and muscle relaxant on the masseter muscle under occlusal wear - an ultrastructural study. Int. J. Morphol., 30(3):999-1006, 2012.

LLLT is known as a new therapeutic approach used for TMD treatment. It stimulates the microcirculation, acts on tissue repair to reduce edema and pain (Mazzeto et al., 2007; Shinozaki et al., 2006). In addition, LLLT keeps the intensity of the force during muscle contraction and may delay its fatigue, and this may increase intracellular ATP levels sufficient to maintain muscle physical effort (Lopes-Martins et al., 2006). However, Gam et al. (1993) have not shown efficiency of LLLT on musculoskeletal disorders.

Therefore, considering that the biological mechanisms resulting from action of LLLT on temporomandibular joint (TMJ), clinical trials remains unclear (Çetiner et al., 2006; Fikáková et al., 2007; Gorgey et al., 2008; Tullberg et al., 2003; Venancio et al., 2005). The aim of the present study was to analyze the influence of lasertherapy and muscle relaxant on the ultrastructural features of masseter muscle under occlusal wear.

\section{MATERIAL AND METHOD}

After approval by the Ethics Committee (Protocol 019/06), forty male adult Wistar rats weighing 300 $\pm 350 \mathrm{~g}$ were included in the study and housed at the animal house of the School of Dentistry of the Federal University of Bahia. The animals were kept on 12:12 h light/ dark cycle and were fed with standard pelted diet and had water ad libitum. The animals were randomly divided into 4 groups with 10 animals each: control group (G-I), occlusal wear group (G-II), occlusal wear + LLLT (G-III), and occlusal wear + muscle relaxant (G-IV).

Under intraperitoneal general anesthesia (ketamine, $0.10 \mathrm{~mL} / 100 \mathrm{~g}+$ xylazine, $0.25 \mathrm{~mL} / 100 \mathrm{mg}$ ), animals of

Table I. Scoring method of tissue injury.

\begin{tabular}{lll}
\hline SCORE & DEGREE OF & MORPHOLOGICAL FEATURES \\
\hline 0 & Normal fiber & $\begin{array}{l}\text { Vacuoles } \\
\text { mitochondrial swelling } \\
\text { intracellular edema }\end{array}$ \\
& Slight & vacuoles \\
& mitochondrial swelling \\
& mitochondria with loss of cristae \\
& & intracellular edema \\
& & vacuoles \\
& & mitochondrial swelling \\
& & mitochondrial with loss of cristae \\
& hypercontraction of myofibrils \\
& disarrangement of myofibrils \\
\hline
\end{tabular}

groups II, III and IV had unilateral amputation of the left inferior and up molar cusps with a round diamond bur under saline irrigation in order to simulate an occlusal wear situation. Care was taken not to cause pulp exposure or damage.

The animals of G-III had the left masseter muscle region shaved and received LLLT $\left(1830 \mathrm{~nm}, 4 \mathrm{~J} / \mathrm{cm}^{2}, 40 \mathrm{~mW}\right.$, f 2mm spot, 'Kondortech' Laser Unit - São Paulo/Brazil) in two contact points, $1 \mathrm{~cm}$ apart, $24 \mathrm{~h}$ after the procedure and it was repeated at every other day during 14 days for half the animals and during 30 days on the other half. Animals of G-IV were treated with a daily intraperitoneal injection of Dantrolene®) (Cristália, São Paulo/Brazil, $2.5 \mathrm{mg} / \mathrm{Kg}$ in $0.5 \mathrm{ml}$ of $\mathrm{H}_{2} \mathrm{O}$ ) beginning 24 hours after occlusal wear simulation.

Half of the animals of each group were killed by overdose of general anesthetics on days 14 and 30 after cusps removal. The ipsilateral masseter muscle of the side of amputated cusps were excised and divided into two samples, being one half routinely processed for electron microscopy.

For transmission electron microscopy, the fresh samples were fixed in $4 \%$ cold glutaraldehyde, containing $0.1 \mathrm{M}(0.1 \mathrm{~mol} / \mathrm{l}$, PBS, pH 7.2 sodium cacodylate buffer, at room temperature, and post-fixed in $1 \%$ osmium tetroxide containing $0.1 \mathrm{M}(0.1 \mathrm{~mol} / \mathrm{l}, \mathrm{pH} 7.2)$ phosphate buffer during one hour, dehydrated in graded acetone, and embedded with Polybed resin. Ultra-thin sections $(70 \mathrm{~nm})$ were cut and stained with uranyl and lead citrate for Zeiss-EM109 transmission electron microscope observation.

For the ultrastructural analysis, the samples were examined by a single previously trained observer using that microscope at magnifications of 4400x, 12000x and 20000x.

The morphological features were established by the observation of these changes in three representative fields (each magnification) in the masseter muscle of each animal (adapted from Bani et al., 1998). The criteria used are reported in the Table I.

Data were reported as mean \pm SEM. The difference between groups were tested using statistically Kruskall Wallis, Mann Whitney, and paired Wilcoxon test. All statistical calculations were performed using Minitab Program, 14.0 software (Minitab, Belo Horizonte, Minas Gerais, Brazil). The level of significance was set at $5 \%(\mathrm{P}<0,05)$. 
LISBOA, M. V.; PINHEIRO, B. A. L.; DOS SANTOS, V. M. A.; BAPTISTA, F. A.; DE SOUSA, C. A. P.; PIRES VALENÇA NETO, P. A. A. \& DOS SANTOS, N. J. Influence of laser therapy and muscle relaxant on the masseter muscle under occlusal wear - an ultrastructural study. Int. J. Morphol., 30(3):999-1006, 2012.

\section{RESULTS}

Group I (control) - This group showed muscle fibers with a normal aspect. The organelles exhibited conspicuous mitochondrias usually arranged duplets at Zine line. The sarcoplasmatic reticulum was well developed, and occasional cytoplasmatic vacuoles were also observed (Fig. 1).

Group II - This group showed many cytoplasmatic vacuoles exhibiting a small size. They were especially numerous in some muscle fibers, however, other fibers did not show to be affected (Fig. 2). The percentage of vacuolated fibers was significantly increased when compared to the control group. In addition, clusters of muscle fibers were also found with disarrangement of myofibrils, hypercontraction and swollen mitochondria with disrupted cristae and cleared matrix (Fig. 3 ). The occlusion wear group (II) at 14 days presented severe injury in $20 \%$ of the fields, $60 \%$ with light or moderate injury, and 20\% without injury. At 30 days, severe injury was only seen in $6.6 \%$ of the fields, with $53.4 \%$ presenting light or moderate injury. The muscle fibers in group II showed more pronounced alterations than those of rats without molar amputation in group I. Besides these characteristics, there was no significant difference between group I and II or between the periods in the groups $(\mathrm{P}>0.05)$.

Group III and Group IV - These groups showed few of the above alterations. Only sparse muscle fibers showed moderate mitochondrial swelling, whereas myofibril hypercontraction was rarely observed (Fig. 4 and 5). In these groups, moderate and severe scores were not as evident as in group II. There were also no statistical differences between these groups and between the experimental periods in each group.

Despite the particular characteristics in each group, the Kruskal-Wallis test demonstrated no interaction between

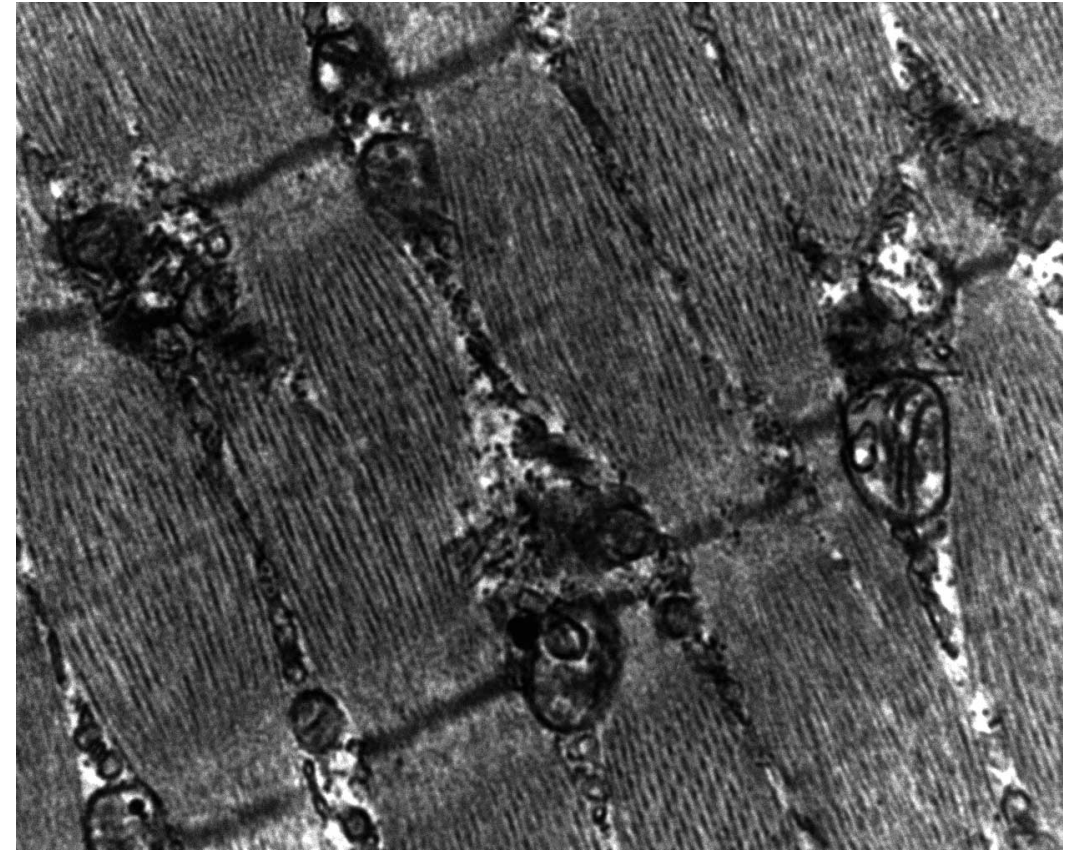

Fig. 1. Control group: thick $\mathrm{Z}$ lines, mitochondria located in pairs at the level of the $\mathrm{Z}$ lines, and well-developed sarcoplasmatic reticulum (x20.000).

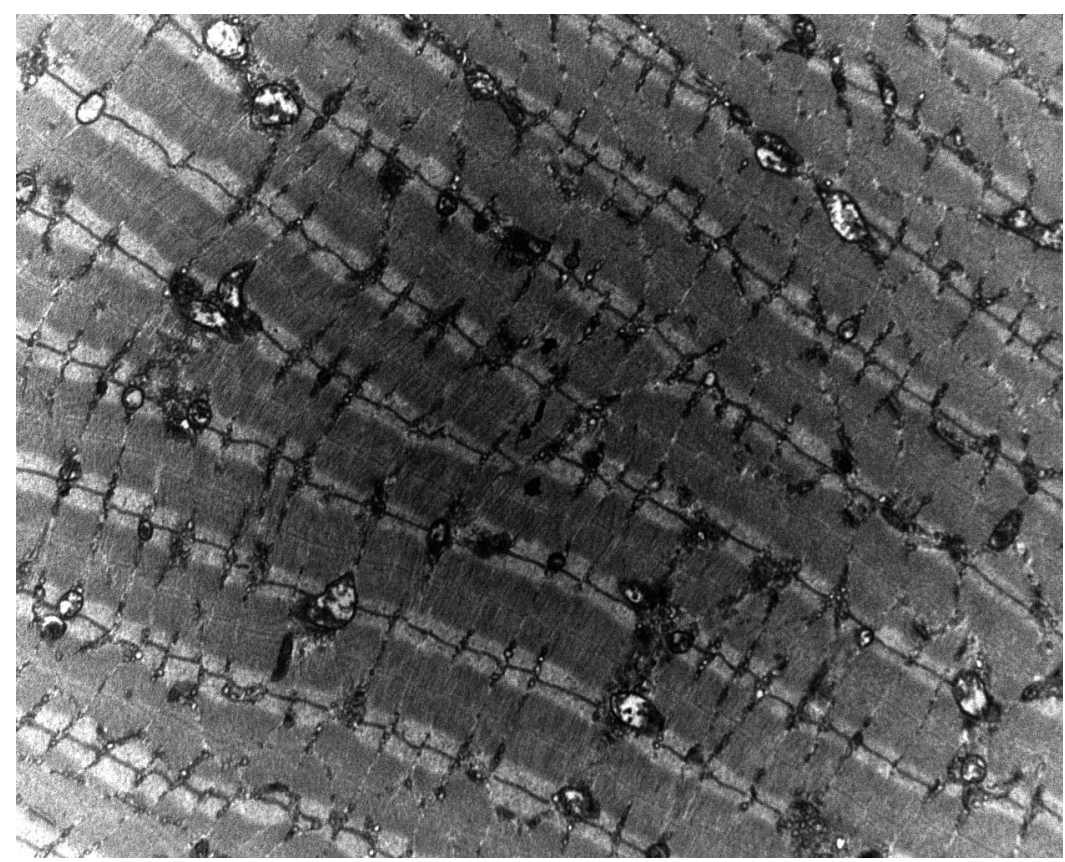

Fig. 2. Rats with molar amputation after 30 days: ipsilateral masseter muscle. Few muscle fibers showing cytoplasmic vacuolization. Presence of swollen mitochondria with disrupted cristae and cleared matrix. (x4.400).

groups I, II, III, IV $(\mathrm{P}=-0.251)$. Paired analysis with Wilcoxon test found no difference between 14 and 30 days on Group II ( $\mathrm{P}=0.2718)$, Group III $(\mathrm{P}=1.000)$, Group IV $(\mathrm{P}=0.8241)$. The score for the electron microscopic examination of specimens are in Fig 6. 


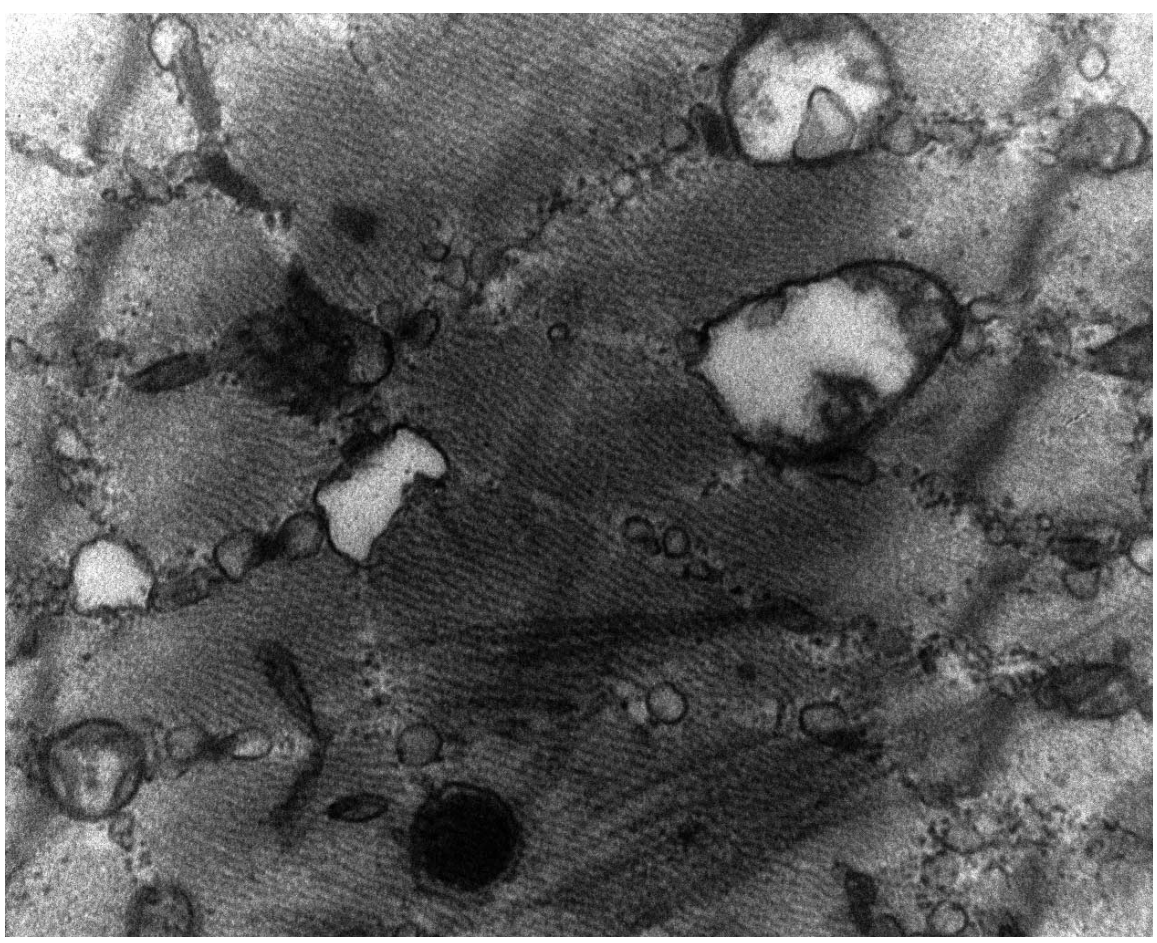

Fig. 3 Rats with molar amputation after 14 days: hypercontracted muscle fiber with disappearance of myofibril I bands, disorganization of myofibrils and disarrangement of contractile filaments $(\mathrm{x} 20.000)$.

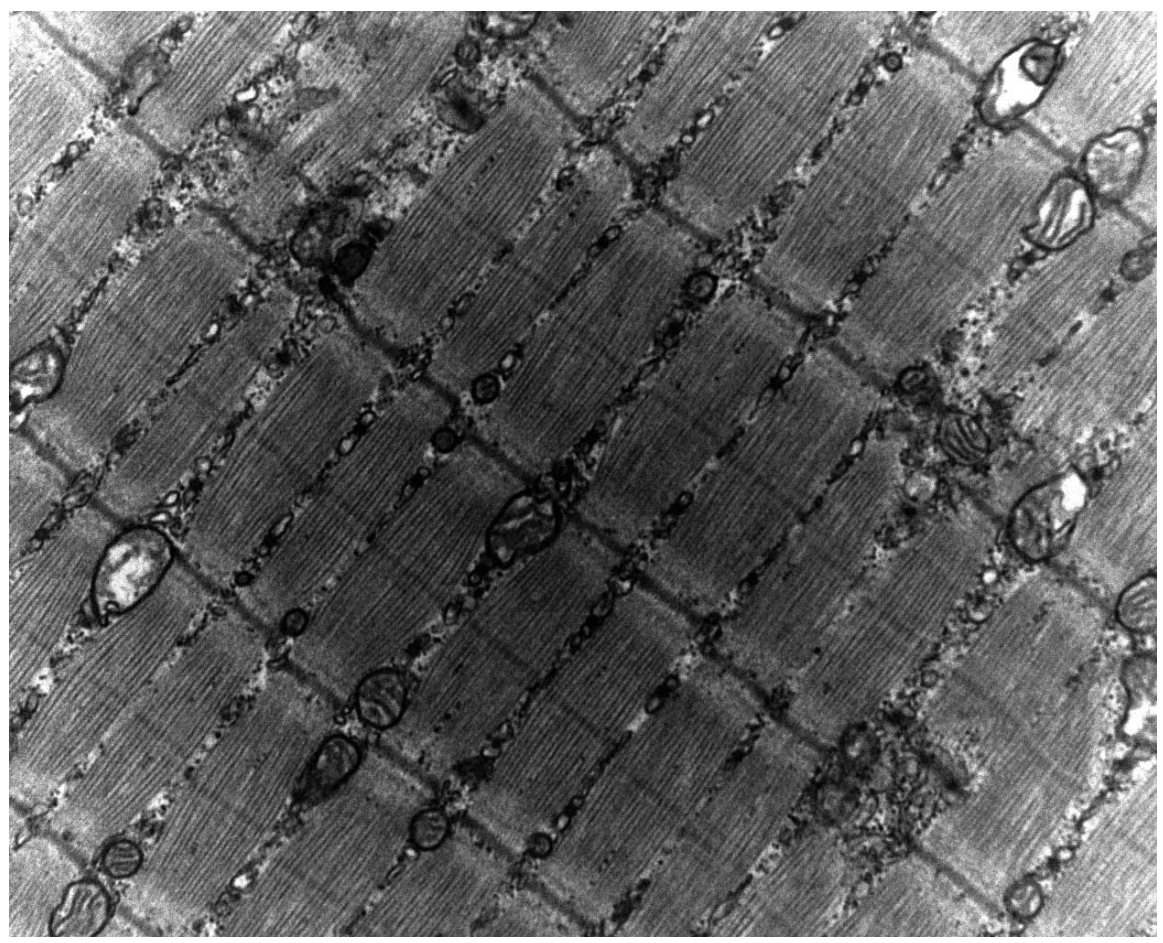

Fig. 4. In the laser group few alterations of muscle tissue could be found. Only sparse muscle fibers showed moderate mitochondrial swelling, although the myofibrils with thick $\mathrm{Z}$ lines; mitochondria located in pairs at the level of the $\mathrm{Z}$ lines and well-developed sarcoplasmatic reticulum.( x 4.400).

\section{DISCUSSION}

Little is known about the association between occlusion and TMD. This study attempted to analyze the morphological features of masseter muscle under occlusal wear and treated with LLLT or muscle relaxant therapy, as no therapy have shown itself capable of overcoming the others.

We used a model of occlusion wear to simulate an altered occlusion. This situation represented patients with lost or worn teeth. This model have been used in previous studies (Bani et al.; Bani \& Bergamini, 2001; Nogueira-Filho et al., 2004) resulting different degrees of morphologic and physiologic alterations on masticatory muscles, specially masseter. It is important to state that malocclusion may influence the functional performance of the masticatory muscles, resulting on muscular overwork and fatigue (Glaros et al., 2007; Pereira et al., 2009; Van Selms et al., 2008).

Previous studies using experimental animals have shown ultrasctructural alterations in the masseter muscle related to occlusal wear (Bani \& Bergamini, 2002; Santiwong et al., 2002) and pterygoid (Bazan et al., 2008; Iyomasa et al., 2008). Some authors as Iyomasa et al. and Bani et al. have shown that muscle fibers and capillaries are sensitive to different masticatory loads, indicating that this may contribute to understand the way in which the muscles adapt to different loads. Although, the group with occlusal wear showed ultra-structural changes at the two experimental periods in this study, they were not enough to demonstrate statistical difference between control group and occlusion wear group. 


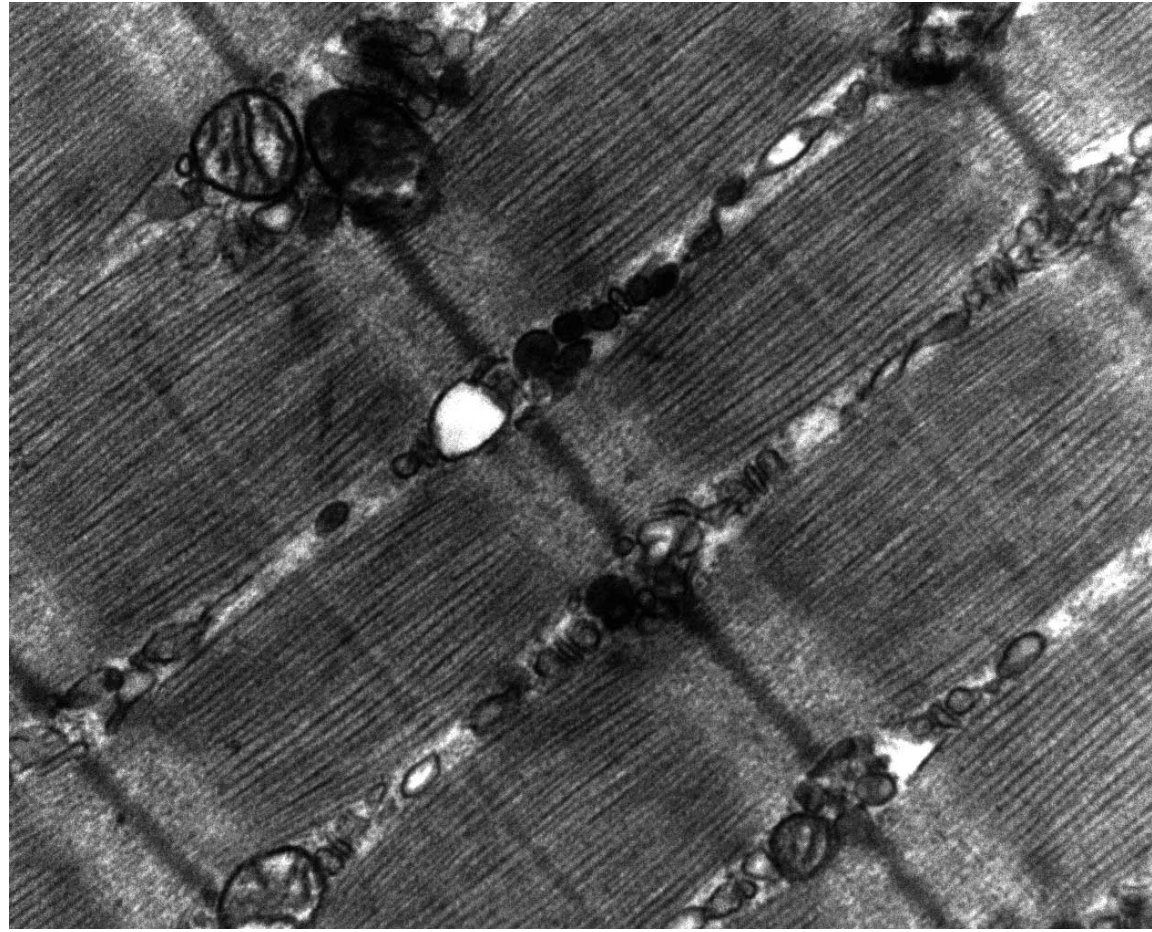

Fig. 5. In the muscle relaxant group few alterations of muscle tissue could be found. The myofibrils with thick $\mathrm{Z}$ lines; mitochondria located in pairs at the level of the $\mathrm{Z}$ lines and well-developed sarcoplasmatic reticulum. Normal aspect ( x20.000).

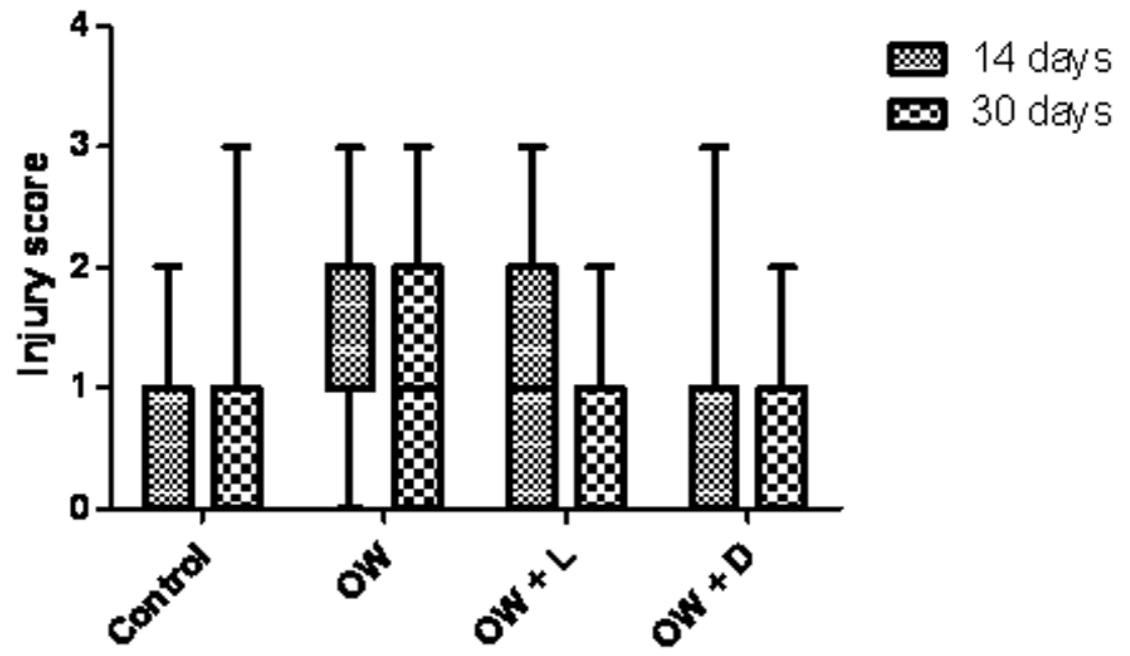

Fig. 6 Injury score for the electron microscopic examination

Therapies used on groups III and IV represented two ways for treatments for TMD. They are reversible therapies mentioned in previous reports as the initial treatment for TMD (Bani \& Bergamini, 2001; Fikácková et al.; Naikmasur et al., 2008), and are effective in reducing pain and muscular tension. The laser protocol used in the present study was chosen in view to its ability to penetrate the muscle tissue, reducing pain and increasing active range of motion and according to our results it seemed to play positive effects on muscle tissue as important injuries were not observed at group III. Furthermore, although the findings of the present study were restricted to a specific set of parameters and that optimal treatment parameters (e.g., wavelength, dosage, number of treatment sessions) have not been, so far, agreed upon (Emshorff et al.; Venancio et al.), previous studies have been beneficial results using Infrared wavelengths (Çetiner et al.; Fikáková et al.; Kato et al., 2006; Kogawa et al., 2005; Leal Júnior et al., 2008).

The laser group (III) showed mild ultrastructural alterations, similar to control group. In this group, only $20 \%$ of fields had filled the criteria for severe and moderate injury. There were no statistical differences between the experimental periods in this group. These findings are similar to previous studies that demonstrated beneficial action of the laser on muscular TMD (Shinozaki et al.; Amaral \& Salvini, 2001; Costardi et al., 2008; Farias, 2005; Frare \& Nicolau, 2008). Despite the laser therapy role on muscle tissues, some authors have performed some studies. Lopes-Martins et al. investigated whether LLLT on visible spectra $(655 \mathrm{~nm})$ can reduce muscular fatigue during tetanic contractions in rats, and concluded that LLLT doses of 0.5 and $1.0 \mathrm{~J} / \mathrm{cm}^{2}$ can prevent development of muscular fatigue in rats during repeated tetanic contractions. Using infrared spectrum, Kato et al. and Kogawa et al. were successful in reducing pain in patients with TMD and increasing active range of motion on the masticatory muscles.

The group IV with dantrolen showed mild ultrastructural 
alterations, also similar to control group. In this group, only $10 \%$ of fields had filled the criteria for moderate and severe injury and $40 \%$ of fields did not show signs of injury. Based on these features, it is possible to state that administration of skeletal muscle relaxant may prevent the occurrence of ultra-morphologic alterations. However, as there were no statistical differences between groups I, II, II and IV, other features especially those related to muscle biochemistry should be further investigated (Lisboa et al., 2010).

Bani et al. studied masseter muscle on a rodent model similar to ours and found vasoconstriction and damages on muscle fibers of animals corresponding to the occlusal wear group. Two years later, Bani \& Bergamini (2001) carried out a study with the same animal model and used dantrolen (10 mg/kg b.w.) as therapy for muscle alterations. These authors demonstrated that the sub-cellular features were similar between control group and maloccluded rats given dantrolen group. In addition in their study, control group and maloccluded rat groups given dantrolen showed results statistically different from those observed in maloccluded rat groups not given dantrolen. This medicine is not usually used for TMJ; thus, it has not been established dose for this purpose yet. The dose of $2.5 \mathrm{mg} / \mathrm{kg}$ b.w used in our experiment represents that earlier dose used for malignant hyperthermia, and is four times smaller than that used by other authors (Bani \& Bergamini, 2001). It may not be enough, as there were no significant differences in our study, however, the ultra-structural characteristics of masseter muscle observed here and in that study carried out by Bani \& Bergamini (2001) showed normal appearance. This might suggest that this medicine can be a new tool focusing on the TMD. In conclusion, it is possible that LLLT and skeletal muscle relaxant play a positive influence on the masseter muscle in rats under occlusal wear, as morphological changes were more evident in occlusal wear group. Thus, our results did not show a cause effect relation between occlusion and TMD, although signs of muscle tissue injury were more evident in that group, indicating moderate action of LLLT and skeletal muscle relaxant as therapeutic agents.

LISBOA, M. V.; PINHEIRO, B. A. L.; DOS SANTOS, V. M. A.; BAPTISTA, F. A.; DE SOUSA, C. A. P.; PIRES VALENÇA NETO, P. A. A. \& DOS SANTOS, N. J. Influencia de la terapia laser y relajante muscular en el músculo masetero bajo oclusión - un estudio ultraestructural . Int. J. Morphol., 30(3):999-1006, 2012.

RESUMEN: El objetivo del estudio fue analizar la influencia de la terapia láser de baja intensidad y del relajante muscular sobre las características ultraestructurales del músculo masetero en el desgaste oclusal. 40 ratas macho Wistar, se dividieron al azar en cuatro grupos: grupo de control (GI), desgaste oclusal (G-II), laserterapia desgaste oclusal (G-III), y relajante muscular desgaste oclusal (G-IV). Bajo anestesia general por vía intraperitoneal, los animales de los grupos II, III y IV sufrieron amputación unilateral de las cúspides de los molares superiores e inferiores para simular una situación de desgaste oclusal. El músculo masetero del G-III recibió la terapia con laser $\left(830 \mathrm{~nm}, 4 \mathrm{~J} / \mathrm{cm}^{2}, 40 \mathrm{~mW}\right.$, f $\left.\sim 2 \mathrm{~mm}\right)$ después del procedimiento el cual se repitió durante 14/30 días. Los animales del G-IV fueron tratados con una inyección diaria de Dantroleno® $\left(2,5 \mathrm{mg} / \mathrm{Kg}\right.$ en $0,5 \mathrm{ml}$ de $\left.\mathrm{H}_{2} \mathrm{O}\right)$. Los animales fueron sacrificados con una sobredosis de anestesia general en los días 14 y 30. Después de la remoción de las cúspides el músculo masetero ipsilateral se extirpó y se dividió en dos, una mitad fue procesada para microscopía de luz y la otra para microscopía electrónica. No hubo diferencias estadísticamente significativas entre cada grupo experimental y el control, así como, entre los períodos en cada grupo experimental. Sin embargo, las fibras musculares en el G-II mostraron los cambios más pronunciados. En conclusión no existe relación causal entre las lesiones de las fibras musculares y la oclusión, a pesar que los signos de lesión de los tejidos musculares fue más evidente en el grupo con desgaste oclusal. Los resultados indican una acción moderada ejercida por la terapia láser y de los relajantes musculares sobre el músculo esquelético.

PALABRAS CLAVE: Laserterapia; Ultraestructura; Oclusión dentaria; Relajante del músculo masetero.

\section{REFERENCES}

Amaral, A.C. \& Salvini, T. Dose-dependency of low energy HeNe lab effect in regeneration on skeletal muscle in mice. Lasers Med. Sci., 16:44-51, 2001.

Bani, D.; Bani, T. \& Bergamini, M. Morphologic and biochemical changes of the masseter muscles induced by occlusal wear: studies in a rat model. J. Dent. Res., 78:1735-44, 1999.
Bani, D. \& Bergamini, L. Dantrolene counteracts the masseter muscle damage induced by artificial oclusal wear: studies in rat model. J. Dent. Res., 80:1990-4, 2001.

Bani, D. \& Bergamini, M. Ultrastructural abnormalities of muscle spindles in the rat masseter muscle with malocclusion-induced damage. Histol. Histopathol., 17:45-54, 2002. 
Bani, D.; Masini, E.; Bello, M. G.; Bigazzi, M. \& Sacchi, T. B. Relaxin protects against myocardial injury caused by ischemia and reperfusion in rat heart. Am. J. Pathol., 152:1367-76, 1998.

Bazan, E.; Issa, J. P.; Watanabe, I. S.; Mandarim-de-Lacerda, C. A.; Del Bel, E. A. \& Iyomasa, M. M. Ultrastructural and biochemical changes of the medial pterygoid muscle induced by unilateral exodontia. Micron, 39:536-43, 2008.

Carrasco, T. G.; Mazzetto, M. O.; Mazzetto, R. G. \& Mestriner, W. Jr. Low intensity laser therapy in temporomandibular disorder: a phase II double-blind study. Cranio, 26:274-81, 2008.

Çetiner, S.; Kahraman, S. A. \& Yücetas, S. Evaluation of lowlevel laser therapy in the treatment of temporomandibular disorders. Photomed. Laser Surg., 24:637-41, 2006.

Costardi, C. H. Z.; Tamachiro, C.; Esteves Júnior, I. \& Gomes, A.C. Efeito do laser de baixa intensidade $(670 \mathrm{~nm})$ após contusão muscular em ratos. Fisioter. Mov., 21:21-30, 2008.

Egermark, I.; Magnusson, T. \& Carlsson, G. E. A 20-year followup of signs and symptoms of temporomandibular disorders and malocclusions in subjects with and without orthodontic treatment in childhood. Angle Orthod., 73:109-115, 2003.

Emshoff, R.; Bösch, R.; Pümpel, E.; Schöning, H. \& Strobl, H. Low-level laser therapy for treatment of temporomandibular joint pain: a double-blind and placebo-controlled trial. Oral Surg. Oral Med. Oral Pathol. Oral Radiol. Endod., 105:4526, 2008.

Farias, V. H. A. Análise da ação do Laser de Baixa Potência em pacientes com Dor Muscular portadores de Desordens Temporomandibulares empregando a Eletromiografia. Dissertation; Vale do Paraíba University, 2005.

Fikácková, H.; Dostálová, T.; Navrátil, L. \& Klaschka, J. Effectiveness of low-level laser therapy in temporomandibular joint disorders: a placebo-controlled study. Photomed. Laser Surg., 25:297-303, 2007.

Frare, J. C. \& Nicolau, R.A. Análise clínica do efeito da fotobiomodulação laser (GaAs - $904 \mathrm{~nm})$ sobre a disfunção temporomandibular. Ver. Bras. Fisioter., 1:37-42, 2008.

Gam, A. N.; Thorsen, H. \& Lonnberg, F. The effect of low-level laser therapy on musculoskeletal pain: a meta-analysis. Pain, 52:63-6, 1993.

Gesh, D.; Bernhardt, O.; Mack, F.; John, U.; Kocher, T. \& Alte, D. Association of malocclusion and functional occlusion with signs of temporomandibular disorders in adults: results of the population- based study of health in Pomerania. Angle Orthod., 74:512-520, 2004.

Glaros, A. G.; Urban, D. \& Locke, J. Headache and temporomandibular disorders: evidence for diagnostic and behavioural overlap. Cephalalgia, 27:542-9, 2007.
Gorgey, A. S.; Wadee, A. N. \& Sobhi, N. N. The effect of lowlevel therapy on electrically induced muscle fatigue: a pilot study. Photomed. Laser Surg., 26:501-6, 2008.

Hersh, E. V.; Balasubramaniam, R. \& Pinto, A. Pharmacologic management of temporomandibular disorders. Oral Maxillofac. Surg. Clin. North Am., 20:197-210, 2008.

Issa, J.P.; Vitti, M.; Da Silva, A.M.; Semprini, M. \& Regalo, S.C. Electromyographical analysis of the masseter muscle in dentulous and partially toothless patients with temporomandibular joint disorders. Electromyogr. Clin. Neurophysiol., 46:263-8, 2006.

Iyomasa, M. M.; Issa, J. P.; Oliveira, F.; Stuani, M. B.; De Oliveira, A. M. \& Watanabe, I. Morphological and histological effects on the medial pterygoid muscle after unilateral exodontia in gerbils. Micron, 39:785-90, 2008.

Kato, M. Y.; Kogawa, E. M.; Santos, C. N. \& Conti, P. C. R. Tens and low-level laser therapy in the management of temporomandibular disorders. J. Appl. Oral Sci., 14:130-5, 2006.

Kogawa, E. M.; Kato, M. Y.; Santos, C. N. \& Conti, P. C. R. Evaluation of the efficacy of low-level laser therapy (11lt) and the microelectric neurostimulation (mens) in the treatment of myogenic temporomandibular disorders: a randomized clinical trial. J. Appl. Oral Sci., 13:280-5, 2005.

Krause, T.; Gerbershagen, M. U.; Fiege, M.; Weibhorn, R. \& Wappler, F. Dantrolene: a review of its pharmacology; therapeutic use and new developments. Anaesthesia, 59:36473,2004

Leal Junior, E. C.; Lopes-Martins, R. A.; Dalan, F.; Ferrari, M.; Sbabo, F. M.; Generosi, R. A.; Baroni, B. M.; Penna, S. C.; Iversen, V. V. \& Bjordal, J. M. Effect of 655-nm low-level laser therapy on exercise- induced skeletal muscle fatigue in humans. Photomed. Laser Surg., 26:419-24, 2008.

Liljeström, M. R.; Le Bell, Y.; Anttila, P.; Aromaa, M.; Jämsä, T.; Metsähonkala, L.; Helenius, H.; Viander, S.; Jäppilä, E.; Alanen, P. \& Sillanpää, M. Headaches in children with temporomandibular disorders have several types of pain and other symptoms. Cephalgia, 25:1054-60, 2005.

Lisboa, M. V.; Lopes, C. B.; Rocha, R.; Ramos, T. A.; Abreu, I. D. N.; Cangussu, M. C. T.; Pinheiro, A. L. B. \& Santos, J. N. Assessment of the Effect of the Use of Laser Light or Dantrolene on Facial Muscle Under Occlusal Wear: A Raman Spectroscopic Study in a Rodent Model. Photomed. Laser Surg., 28:S1-S7, 2010.

Lopes-Martins, R. A. B.; Marcos, R. L.; Leonardo, O. S.; Prianti, A. C. Jr.; Muscará, M. N.; Aimbire, F.; Frigo, L.; Iversen, V. V. \& Bjordal, J. M. Effect of low-level laser (Ga-Al-As $655 \mathrm{~nm}$ ) on skeletal muscle fatigue induced by electrical stimulation in rats. J. Appl. Physiol., 101:283-8, 2006. 
Mazzetto, M. O.; Carrasco, T. G.; Bidinelo, E. F.; Pizzo, R. C. A. \& Mazzetto, R. G. Low intensity laser application in temporomandibular disorders: a phase I double-blind study. $J$. Craniomandib. Pract., 25:186-92, 2007.

Naikmasur, V.; Bhargava, P.; Guttal, K. \& Burde, K. Soft occlusal splint therapy in the management of myofascial pain dysfunction syndrome: A follow-up study. Indian J. Dent. Res., 19:196-203, 2008

Niemi, P. M.; Le Bell, Y.; Kylmälä, M.; Jämsä, T. \& Alanen, P. Psychological factors and responses to artificial interferences in subjects with and without a history of temporomandibular disorders. Acta Odontol. Scand., 64:300-5, 2006.

Nogueira-Filho, G. R.; Fróes Neto, E. B.; Casati, M. Z.; Reis, S. R.; Tunes, R. S.; Tunes, U. R.; Sallum, E. A.; Nociti, F. H. Jr. \& Sallum, A. W. Nicotine effects on alveolar bone changes induced by occlusal trauma: a histometric study in rats. $J$. Periodontol., 75:348-52, 2004.

Okano, N.; Baba, K. \& Igarashi, Y. Influence of altered occlusal guidance on masticatory muscle activity during clenching. $J$. Oral Rehabil., 34:679-84, 2007.

Pereira, L .J.; Steenks, M. H.; de Wijer, A.; Speksnijder, C. M. \& Van der Bilt, A. Masticatory function in subacute TMD patients before and after treatment. J. Oral Rehabil., 36:391-402, 2009.

Prasad, K. C.; Sreedharan, S.; Prasad, S. C. \& Chakravarthy, Y. Tuberculosis of the temporomandibular joint and parotid secondary to tuberculus otitis media. Otolaryngol. Head Neck Surg., 137:974-5, 2007.

Rodrigues, K. A. \& Ferreira, L. P. Eletromiografia dos músculos masseteres na mastigação habitual em indivíduos com e sem má oclusão. Rev. Dent. Press Ortodon. Ortoped. Facial, 8:10714, 2003.

Santiwong, P.; Muramoto, T.; Soma, K. \& Takano, Y. Growthassociated protein-43 immunohistochemical and ultrastructural changes in jaw muscle spindles of the rat following loss of occlusion. Arch. Oral. Biol., 47:227-37, 2002.

Shinozaki, E. B.; Paiva, G.; Zanin, F. A. A. \& Brugnera Junior, A. Avaliação eletromiográfica de pacientes com DTM após a laserterapia. $R G O$, 54:334-9, 2006.

Sonnesen, L. \& Svensson, P. Temporomandibular disorders and psychological status in adult patients with a deep bite. Eur. J. Orthod., 30:621-9, 2008.

Suvinen, T. I. \& Kemppainen, P. Review of clinical EMG studies related to muscle and occlusal factors in healthy and TMD subjects. J. Oral Rehabil., 34:631-44, 2007.

Tullberg, M.; Alstergren, P. J. \& Ernberg, M. M. Effects of lowpower laser exposure on masseter muscle pain and microcirculation. Pain, 105:89-96, 2003.
Türp, J. C.; Jokstad, A.; Motschall, E.; Schindler, H. J.; WindeckerGétaz, I. \& Ettlin, D.A. Is there a superiority of multimodal as opposed to simple therapy in patients with temporomandibular disorders? A qualitative systematic review of the literature. Clin. Oral Impl. Res., 18:S189-S192, 2007.

Van Selms, M. K. A.; Lobbezoo, F.; Visscher, C. M. \& Naeije, M. Myofascial temporomandibular disorder pain; parafunctions and psychological stress. J. Oral Rehabil., 35:45-52, 2008.

Venancio, R. A.; Camparis, C. M. \& Lizarelli, R. F. Low intensity laser therapy in the treatment of temporomandibular disorders: a double-blind study. J. Oral Rehabil., 32:800-7, 2005.

Correspondence to:

Jean Nunes dos Santos

Av. Araujo Pinho, 62

Canela, Salvador, 40110-150

Bahia

BRAZIL.

Phone: +557132839019

Fax : +55 7132838962

E-mail: jeanunes@ufba.br

Received: 20-02-2012

Accepted: 08-05-2012 